\title{
ECONOMIA SOLIDÁRIA E INTERSECCIONALIDADE: DESAFIOS DA AUTOGESTÃO NA ATUAÇÃO DA ITCP/UNICAMP
}

\author{
SOLIDARY ECONOMY AND INTERSECTIONALITY: CHALLENGES OF \\ SELF-MANAGEMENT IN ITCP / UNICAMP'S PERFORMANCE
}

\author{
Amanda Silva ${ }^{1}$ \\ Bárbara $\mathrm{Melo}^{2}$ \\ Lais Fraga ${ }^{3}$ \\ Larissa Andrade ${ }^{4}$ \\ Samara Santos ${ }^{5}$
}

\section{RESUMO}

Este artigo reflete sobre os limites da Economia Solidária (ES), considerando que as principais acepções do termo não incorporam uma reflexão acerca das desigualdades raciais e de gênero. Para isso, parte dos desafios da autogestão nos Empreendimentos de Economia Solidária (EES), considerando a intersecção dessas desigualdades no âmbito dos empreendimentos incubados pela Incubadora Tecnológica de Cooperativas Populares, da Universidade Estadual de Campinas (ITCP/Unicamp), entre 2018 e 2020. Este artigo contextualiza o surgimento das ITCPs como prática extensionista durante o avanço das políticas neoliberais entre 1980 e 1990, especialmente durante o governo Fernando Henrique Cardoso. Ademais, propõe uma abordagem interseccional das desigualdades, no âmbito da ES. Por fim, pretende argumentar que, mesmo sendo um eixo de resistência ao avanço do capitalismo neoliberal, a ES não está isenta de contradições e estigmas que embasam as relações de trabalho convencional, questões essas que desafiam a estruturação sólida de suas diretrizes, dentre elas a autogestão.

Palavras-chave: economia solidária, interseccionalidade, incubadoras tecnológicas de cooperativas populares, raça, gênero.

\footnotetext{
ABSTRACT

This article reflects on the limits of Solidarity Economy (ES), considering that its main meanings do not incorporate a reflection on racial and gender inequalities. It starts with the challenges of self-management in Solidarity Economy Enterprises (EES), considering the intersection of these inequalities, within the scope of the enterprises incubated by the Technological Incubator of Popular Cooperatives, of the State University of Campinas (ITCP/Unicamp), between 2018

1 Graduanda em Química (Bacharelado em Química Tecnológica e Licenciatura) pelo Instituto de Química (IQ) da Universidade Estadual de Campinas (Unicamp). Pesquisadora-extensionista da ITCP/Unicamp.

2 Graduanda em Ciências Sociais (Bacharelado em Sociologia e Licenciatura) pelo Instituto de Filosofia e Ciências Humanas (IFCH) da Universidade Estadual de Campinas (Unicamp). Pesquisadora-extensionista da ITCP/Unicamp.

3 Professora da Faculdade de Ciências Aplicadas (FCA) da Universidade Estadual de Campinas (Unicamp). Graduada em Engenharia de Alimentos (2003), mestre (2007) e doutora (2012) em Política Científica e Tecnológica pela Unicamp. Atua na extensão por meio na Incubadora Tecnológica de Cooperativas Populares (ITCP/Unicamp) desde 2004. Atualmente é coordenadora da ITCP/Unicamp.

4 Graduanda em Engenharia Elétrica pela Universidade Estadual de Campinas (Unicamp). Pesquisadora-extensionista da ITCP/Unicamp.

5 Bacharela em Administração Pública pela Faculdade de Ciências Aplicadas/Unicamp. Pesquisadora-extensionista da ITCP/Unicamp.
} 
and 2020. This article contextualizes the emergence of ITCPs as an extension practice during the advance of neoliberal policies between 1980 and 1990, especially during the Fernando Henrique Cardoso administration. Furthermore, an intersectional approach to inequalities is proposed within the scope of ES. Finally, it argues that, although ES resists the advance of neoliberal capitalism, it is not exempt from contradictions and stigmas that underlie conventional labor relations, issues that challenge the solid structuring of its guidelines, among them selfmanagement.

Keywords: solidarity economy, intersectionality, technological incubator of popular cooperatives, race, gender.

\section{INTRODUÇÃO}

Este artigo tem como objetivo refletir sobre os limites da Economia Solidária (ES) ao considerar que as principais acepções do termo não têm incorporado uma reflexão acerca das desigualdades raciais e de gênero. Este trabalho realiza uma incursão bibliográfica nos temas Economia Solidária e interseccionalidade e analisa a prática extensionista realizada pela ITCP/ Unicamp durante o período de 2018 a 2020, buscando refletir acerca dos desafios da autogestão no contexto do avanço das políticas neoliberais no país.

Durante esse período de atuação, a ITCP/Unicamp esteve dividida em três equipes interdisciplinares de incubação ${ }^{6}$, atingindo populações rurais e urbanas, alvos de diferentes processos de marginalização, mas especialmente de raça, gênero e classe. A Equipe Corpo atua com um grupo de mulheres no Jardim Bassoli, periferia de Campinas-SP, que cultiva uma horta urbana na Escola Estadual Carlos Lehman, a Horta das Margaridas. A Equipe Rede atua com catadoras e catadores de materiais recicláveis no mesmo município, especificamente com a Cooperativa de Materiais Recicláveis Santa Genebra. Por fim, a Equipe Agricultura atua com o Coletivo de Produtoras Elizabeth Teixeira, do acampamento Elizabeth Teixeira, ligado ao Movimento dos Trabalhadores Rurais Sem Terra (MST), em Limeira-SP. Mesmo com suas especificidades, os três empreendimentos apresentam, entre outros aspectos, um viés comum: a perspectiva coletiva e autogerida, coerente com os princípios da Economia Solidária.

Alguns autores atribuem o surgimento da Economia Solidária, na Europa do século XIX, ao resultado de movimentos associativos de operários, simbolizando um ímpeto de transformação social (FRANÇA, 2002, p. 11 apud SILVA, 2011), em um contexto cujo desenho socioeconômico evidenciava uma sociedade classista e condições de trabalho desumanas. Como aponta Paul Singer, até o final do século XIX "as condições de trabalho eram tão ruins e desesperadoras que a única opção era rebelar-se” (SINGER, 2003, p. 121 apud SILVA, 2011, [n.p.]).

$\mathrm{O}$ conceito e as práticas relacionadas à Economia Solidária são amplos e diversos, não podendo ser encarados de forma anacrônica, uma vez que refletem a sociedade e o contexto histórico, político e econômico no qual estão inseridos, assim como seus agentes promotores, suas características e seus instrumentos. A ES refere-se à organização de produtores, consumidores e poupadores com duas especificidades: a primeira, é que estimulam a solidariedade entre os membros mediante a prática de autogestão; e a segunda está no fato de praticarem a solidariedade com a população trabalhadora em geral, com ênfase na ajuda aos mais desfavorecidos (SINGER, 2002).

\footnotetext{
${ }^{6}$ Incubação é o processo de assessoria técnico, educacional e político realizado pela ITCP/Unicamp com grupos populares coletivos e autogeridos com intuito de geração de trabalho e renda.
} 
Em meio a um contexto no qual a recém-concebida sociedade capitalista defendia que o "mercado seria capaz de autorregular-se para o bem de todos e que a competição seria o melhor modo de relação entre os atores sociais" (Grupo de Trabalho de Economia Solidária do FSM, 2008, p. 108 apud SILVA, 2011, [n.p.]), tomaram corpo e força os movimentos reivindicatórios sindicais e cooperativos com outras visões de trabalho. As longas jornadas de trabalho, as condições insalubres e os baixos salários evidenciaram que tal "bem comum" e "ação próspera do mercado" seriam, na realidade, restritas a alguns agentes desse sistema, em especial aos mantenedores dos meios produtivos e setores de maior influência econômica.

Apesar do potencial aparente das primeiras experiências, não tardou até que as iniciativas cooperativistas começassem a sentir um enfraquecimento, consequência, sobretudo, da crise do emprego enfrentada pela Europa no início do século XIX, decorrente esta da Greve Patronal de 1834. Com altos índices de desemprego, algumas experiências cooperativas passaram por drásticas mudanças operacionais, sendo que muitas "cresceram e se profissionalizaram tanto que perderam os princípios solidários iniciais e incorporaram a mesma lógica do mercado tradicional capitalista" (SILVA, 2011, [n.p.]).

Dessa forma, um novo momento histórico foi vivenciado pelo movimento cooperativista. A ascensão do trabalho assalariado, assim como algumas medidas estatais, promoveram o abafamento das questões trabalhistas. Para Singer (2002), o período de 1940 a 1970 é caracterizado como uma fase de acomodação do assalariado, que refletiu tanto o crescimento da força dos sindicatos quanto o descrédito atribuído à Economia Solidária após a falta de êxito das primeiras experiências socialmente marcantes (SILVA, 2011).

Cláudio Nascimento (2019), por sua vez, traça uma longa e detalhada história da luta dos trabalhadores pela construção da perspectiva autogestionária, elemento fundante da Economia Solidária. Essa perspectiva, que ganha destaque a partir dos anos 1960, tem suas origens na Europa do século XII e um de seus marcos é a experiência da Comuna de Paris (1871). No entanto, o autor aponta diversas experiências com inspirações autogestionárias na América Latina, Ásia, África etc. A contribuição de Cláudio Nascimento amplia a perspectiva da origem da Economia Solidária e considera outros sujeitos nessa construção de alternativas econômicas, de produção e organização da sociedade.

Diante dessa reconstrução histórica dos princípios da Economia Solidária, pode-se inferir que, pela centralidade do pensamento de Paul Singer e pelo foco da atenção nas experiências europeias, são poucas as abordagens que consideram outras formas de desigualdade, a não ser as de classe. Isto é, considera-se que os fundamentos teóricos da perspectiva hegemônica da Economia Solidária se distanciam das desigualdades pautadas na raça e no gênero dos sujeitos que compõem as classes populares. Evidentemente, não se deve fazer análises anacrônicas acerca de um conceito; porém, estes devem ser revisados e ressignificados conforme as transformações sociais, atribuindo-lhe a análise sobre seus sujeitos e seu contexto de surgimento.

Sendo assim, ao considerar as crescentes demandas do movimento negro e dos movimentos feministas no Brasil, especialmente após a ascensão dos governos progressistas nos anos 2000 e sua brusca interrupção em 2016, é preciso haver uma crítica do conceito de Economia Solidária, inserindo uma abordagem interseccional sobre o tema e considerando os desdobramentos do avanço de políticas neoliberais nos últimos anos.

Este artigo tem o intuito de contribuir para a reflexão sobre esse limite do conceito de Economia Solidária e, para isso, está dividido em quatro seções. Na primeira, "Economia Solidária: uma alternativa à 'boa governança' neoliberal”, é feita uma recapitulação histórica do conceito de neoliberalismo e da crítica que Christian Laval e Pierre Dardot fazem às leituras 
desse conceito. Ainda na primeira seção, o artigo apresenta o surgimento das ITCPs no contexto de avanço neoliberal do governo Fernando Henrique Cardoso, e de que modo essa iniciativa, particularmente a ITCP/Unicamp, tem apresentado uma práxis passível de compor os esforços da Economia Solidária como alternativa à economia capitalista.

$\mathrm{Na}$ segunda seção, "Abordagem interseccional sobre a Economia Solidária", é apresentada a discussão sobre a articulação das desigualdades de raça, gênero e classe no âmbito da Economia Solidária. Faz-se uma breve reconstrução histórica do trabalho no Brasil, de modo a considerar que esta, em geral, é feita considerando apenas a história do trabalho assalariado, excluindo o período da escravidão. Além disso, pretende-se mobilizar o conceito de interseccionalidade, cunhado por $\mathrm{K}$. Crenshaw, mas amplamente utilizado pelas pensadoras feministas negras como metodologia de análise que traz para o centro a encruzilhada entre as categorias de desigualdades, que atuam criando sobreposições de opressões de raça, gênero, sexualidade, classe, geografia etc. Adota-se para isso o ponto de vista interseccional, pois a partir deste é permitido compreender aspectos das opressões que estruturam o mundo do trabalho (e são estruturadas por ele) nos empreendimentos parceiros da ITCP.

A seção "Relatos de experiência nos EES da ITCP/Unicamp" apresenta uma breve descrição sobre os empreendimentos de Economia Solidária incubados pela instituição no período entre 2018 e 2020. Pretende-se, pelos relatos, expor as contradições existentes ao construir uma prática autogestionária nos EES, em um contexto de avanço do neoliberalismo. Em outras palavras, os esforços para romper com a lógica de mercado característica do neoliberalismo não estão isentos de contradições. Considerando o recorte específico do trabalho em 2020, deve-se levar em conta os efeitos da pandemia de covid-19, uma vez que esta representou um grande desafio à realização das atividades, já que o trabalho da ITCP/Unicamp requer uma interação profunda e viva entre a instituição e os grupos incubados. Abordar-se-á brevemente como a solidariedade popular tem beneficiado a mobilização dos EES incubados no contexto da pandemia.

Por fim, as considerações finais apresentam uma articulação entre as seções anteriores, a fim de refletir sobre o que Marielle Franco afirmou ao longo de sua trajetória: as minorias sociais, especialmente as mulheres negras, não são subjugadas à dinâmica de opressão da sociedade, mas centralizam ações criativas e de enfrentamento a elas. Nesta seção, pretende-se argumentar, ainda, que é necessário reconhecer que, apesar da autogestão e da Economia Solidária guiarem o trabalho das ITCPs, atentar-se para as necessidades imediatas dos grupos também faz parte desse processo de construção. Assim, caracterizar a Economia Solidária em termos de gênero e raça é importante, inclusive, para se discutir as dificuldades da autogestão nesses grupos. A estrutura racista e machista da sociedade colocou, durante anos, as mulheres negras e pobres em atividades de subordinação. Isso se contrapõe a uma ideia de participação ativa e igualitária.

A fim de contemplar os objetivos supracitados, isto é, de refletir sobre o conceito de Economia Solidária com base em uma abordagem interseccional das desigualdades, este artigo recorrerá a duas abordagens teórico-metodológicas. Primeiramente, será feita uma revisão bibliográfica com intuito de aprofundar a reflexão sobre os desafios da autogestão nos empreendimentos de Economia Solidária no contexto do avanço das políticas neoliberais, considerando a intersecção das desigualdades de gênero, raça e classe. Ao acompanhar tal horizonte teórico-metodológico, aponta-se para a importância dessas intersecções no âmbito da Economia Solidária, a fim de compor uma alternativa robusta à economia capitalista. Em seguida, recorrer-se-á ao acúmulo das experiências vividas pelas educadoras populares e autoras deste artigo junto aos EES incubados pela ITCP/Unicamp. Esta análise permite uma reflexão crítica sobre a prática da Economia Solidária nos grupos, colaborando para uma avaliação de como a ausência do debate da interseccionalidade dificulta a atuação autogestionária. 
A construção das ideias que compõem este trabalho está profundamente associada ao cotidiano das atividades extensionistas das autoras, por meio de uma metodologia de atuação que consiste em, com base na Educação Popular, buscar, junto aos grupos incubados, a consolidação do espaço de trabalho enquanto um processo pedagógico de emancipação. Com isso, a ITCP se soma no esforço para construção e execução de uma pedagogia do trabalho associado (TIRIBA, 2001), que seja capaz de contribuir para as necessidades concretas enfrentadas pelos grupos populares de forma coerente com os princípios da autogestão. O funcionamento da ITCP/Unicamp prevê que todos os educadores e educadoras populares estejam inseridos(as) em uma equipe de incubação e em um grupo de estudos, no qual busca referenciais teóricometodológicos para a prática. Esse encontro entre teoria e prática nos leva à construção coletiva de novos referenciais teórico-metodológicos, por meio da pesquisa-ação.

\section{ECONOMIA SOLIDÁRIA: UMA ALTERNATIVÀ̀ "BOA GOVERNANÇA" NEOLIBERAL}

Em um momento pós-Segunda Guerra Mundial (1939-1945), em que o mundo ocidental ainda buscava sua reconstrução, o quadro de desemprego, retração econômica e altos índices de inflação abriram espaço para o questionamento do pensamento keynesiano e do Estado de Bem-Estar social até então vigente desde o colapso pós-Primeira Guerra Mundial (1914-1918). Assim, na década de 1970, diante de um novo contexto social, econômico, político e tecnológico, o mundo capitalista precisou se reinventar.

Pautado na presença e no papel do Estado como regulador das atividades sociais, a incluir dinâmica econômica, o Estado de Bem-Estar Social teve vigência na Europa logo após a Primeira Guerra, pretendendo a reconstrução da Inglaterra e outros países no período (ANDERSON, 1995). Apesar do êxito do projeto entre as décadas de 1950 e 1960, com o "capitalismo avançado entrando numa longa fase de auge sem precedentes, sua idade de ouro", como aponta Perry Anderson em seu artigo "Balanço do Neoliberalismo" (1995), a forte presença do Estado sobre a economia também gerou reações de oposição de algumas filosofias econômicas. Uma delas foi protagonizada pela Escola Austríaca, representada pelo economista Friedrich Hayek, um dos grandes nomes de um novo projeto econômico que visava à redução da participação estatal, o neoliberalismo.

A obra $O$ caminho da servidão, escrito por Hayek em 1944, é considerado o textobase para essa nova orientação econômica. "Trata-se de um ataque apaixonado contra qualquer limitação dos mecanismos de mercado por parte do Estado, denunciada como uma ameaça letal à liberdade, não somente econômica, mas também política" (ANDERSON, 1995, p. 1). Ainda segundo a mesma referência, para Hayek, "apesar de suas boas intenções, a socialdemocracia moderada inglesa conduz ao mesmo desastre que o nazismo alemão - uma servidão moderna" (ANDERSON, 1995, p. 1).

A polêmica contra a regulação social, no entanto, tem uma repercussão um pouco maior. Hayek e seus companheiros argumentavam que o novo igualitarismo (muito relativo, bem entendido) deste período, promovido pelo Estado de bem-estar, destruía a liberdade dos cidadãos e a vitalidade da concorrência, da qual dependia a prosperidade de todos. Desafiando o consenso oficial da época, eles argumentavam que a desigualdade era um valor positivo - na realidade imprescindível em si -, pois disso precisavam as sociedades ocidentais. Esta mensagem permaneceu na teoria por mais ou menos 20 anos (ANDERSON, 1995, p. 10). 
Durante aproximadamente três décadas, o movimento neoliberal esteve fora da concepção econômica mundial, tendo seu fortalecimento a partir da década de 1970, com a crise do Estado de Bem-Estar, quando o mundo enfrentou um novo momento de forte recessão econômica, combinado a um estado de altos índices inflacionários e baixas taxas de crescimento econômico dos países. Aproveitando-se do momento de fragilidade política e social, os neoliberais exploraram essa oportunidade para criar o novo inimigo social e, por fim, alcançar espaços políticos.

As raízes da crise, afirmavam Hayek e seus companheiros, estavam localizadas no poder excessivo e nefasto dos sindicatos e, de maneira mais geral, do movimento operário, que havia corroído as bases de acumulação capitalista com suas pressões reivindicativas sobre os salários e com sua pressão parasitária para que o Estado aumentasse cada vez mais os gastos sociais (ANDERSON, 1995, p. 10).

Com os "males" decorrentes desses processos reivindicatórios em voga (redução do lucro das empresas, processos inflacionários, entre outros), a crise seria vista pelos neoliberais como um caminho óbvio. Mas como superá-la? Na visão neoliberal, a solução seria o enfraquecimento do Estado na economia e no controle do mercado, junto a seu fortalecimento no comando sindical, além do domínio de gastos, em especial nas esferas sociais. A estabilidade monetária deveria ser o projeto-alvo de todo governo, com a redução de custos considerados não essenciais, antes base do Estado de Bem-Estar, assim como a necessidade de restauração da taxa "natural" de desemprego, necessária para o enfraquecimento sindical e a desvalorização da mão-de-obra. Além do mais, reformas fiscais seriam fundamentais, pela visão neoliberal, para a dinamização da economia, entre elas a redução de impostos sobre rendimentos mais altos e incentivos fiscais para empresas e empregadores (ANDERSON, 1995).

Desta forma, uma nova e saudável desigualdade iria voltar a dinamizar as economias avançadas, então às voltas com uma estagflação, resultado direto dos legados combinados de Keynes e de Beveridge, ou seja, a intervenção anticíclica e a redistribuição social, as quais haviam tão desastrosamente deformado o curso normal da acumulação e do livre mercado. O crescimento retornaria quando a estabilidade monetária e os incentivos essenciais houvessem sido restituídos (ANDERSON, 1995, p. 10-11).

A implementação das práticas neoliberais não se deu do dia para a noite, mas aconteceu em quase uma década de implementação gradativa em meio a movimentos de resistência, até que fosse observado seu fortalecimento, resultado, sobretudo, da ascensão política de representantes partidários da ideologia nos dois principais sítios do capitalismo daquele momento: Margaret Thatcher na Inglaterra, em 1979, e Ronald Reagan nos Estados Unidos, em 1982. Desse momento em diante, gradualmente essa nova perspectiva econômica foi se alastrando pelo Ocidente e desestruturando as demais formas de Estado.

Caberia ainda uma discussão sobre as formas de implementação dessa visão de mundo e, segundo as postulações de Hayek, de liberdade do mercado e, consequentemente do indivíduo que, na realidade, se manifestou em diferentes pesos e medidas nos diferentes países. Exemplificando objetivamente, enquanto alguns países da Europa implantavam as medidas neoliberais sem tantos cortes sociais, visando fundamentalmente ao balanço orçamentário, na América Latina movimentos mais duros e radicais de cortes e desempregos puderam ser observados (ANDERSON, 1995), evidenciando ainda outras relações político-econômicas de subordinação das ex-colônias e o que hoje se conhece como países subdesenvolvidos.

Leituras mais contemporâneas sobre o neoliberalismo apresentam críticas e reformulações acerca do conceito. Após atravessar diversas crises, o neoliberalismo continua 
sendo uma forma de organização social vigente. Segundo Christian Laval e Pierre Dardot, em A nova razão do mundo: ensaio sobre a sociedade neoliberal, a expressão contemporânea do neoliberalismo não instaurou um novo modo de acumulação, mas formou uma nova sociedade, novos comportamentos, novas formas de relação com o outro e consigo mesmo.

Para os autores, há um equívoco de diagnóstico a respeito do que se tem compreendido sobre essa forma de organização social, a qual não configura somente uma ideologia e uma política econômica fundada nesta ideologia, mas é uma racionalidade que estrutura governantes e governados. Em suas palavras, "o neoliberalismo pode ser definido como um conjunto de discursos, práticas e dispositivos que determinam um novo modo de governo dos homens segundo o princípio universal da concorrência" (LAVAL; DARDOT, 2016, p. 17). Sendo assim, a dimensão do mercado deixa de ser o espaço onde se disputam interesses privados, como afirmava Smith, e torna-se um processo subjetivo que adequa os sujeitos à lógica da concorrência. Ainda segundo os autores, a concorrência, no entanto, não expressa equilíbrio, mas lutas e rivalidades que ultrapassam a dimensão econômica e atravessam a dimensão política e afetiva das relações sociais.

Além disso, deve-se ressaltar a característica política da razão neoliberal: o Estado é uma empresa e se organiza como tal. Assim, de acordo com Laval e Dardot, a boa governança dos Estados nacionais implica que estes, junto à iniciativa privada, desenvolvam mecanismos para que a gestão política integre o mercado nacional. Isto é, o Estado incorpora as normas e a lógica de competitividade definidas pela iniciativa privada. Assim, arraigado na perspectiva neoliberal, o Estado constrói políticas que beneficiam o setor privado e promovem o desmantelamento das políticas de proteção social. Nesse contexto, os cidadãos e as cidadãs tornam-se meros consumidores, compradores de serviços, os quais não cobram por justiça social. No entanto, deve-se ressaltar que, ao considerar a perspectiva foucaultiana dos autores, o ato de governar não corresponde ao desenvolvimento de políticas econômicas, mas à condução da conduta dos sujeitos.

É sabido que no Brasil a iniciativa neoliberal se instalou e avançou em meados dos anos 1990, especificamente durante o governo Fernando Henrique Cardoso. É preciso reconhecer e expressar o óbvio: a lógica neoliberal, especialmente em um país como o Brasil, assolado pela desigualdade social, não garante que todos os sujeitos possam concorrer livremente no mercado, tal como compreendido por Laval e Dardot. Ao generalizar o princípio da concorrência e construir sujeitos competidores, o que os autores chamam de sujeitos empresariais, engendrase um violento processo de marginalização. Assim, pode-se inferir que os governos neoliberais não favorecem a população em geral.

Desde a queda dos governos progressistas, a América Latina tem enfrentado uma nova onda neoliberal. No Brasil, o crescente quadro de informalidade não pode ser dissociado das consequências de políticas neoliberais implementadas no país nos últimos anos. A Reforma Trabalhista, por exemplo, prevê a flexibilização de direitos trabalhistas, o que viabiliza o surgimento de postos de trabalho intermitentes ou ainda sem vínculos empregatícios. Segundo o mais recente censo do Instituto Brasileiro de Geografia e Estatística (IBGE, 2019), a informalidade do trabalho atingiu níveis recordes no país: aproximadamente $41,1 \%$ da população ocupada se encontrava em condição de informalidade. Em contrapartida, postos de trabalho formais têm exigido cada vez mais qualificação e dedicação do empregado, para que este consiga suprir as demandas de uma sociedade dinâmica e globalizada, a qual requer, a todo o momento, maiores inovações com menores custos. Nas palavras do desembargador Sebastião Geraldo de Oliveira "vive-se em uma sociedade em que as exigências do trabalho são mais 'densas, tensas e intensas', gerando a contradição na existência de índices crescentes de doenças 
decorrentes do excesso de trabalhos concomitantes a índices que denunciam o crescimento ou elevado desemprego" (SILVA, 2011, [n.p.]).

No entanto,

É diante desta conjuntura que novas oportunidades se abrem. Trabalhadores de todo o mundo, movimentos sociais, estudantes, técnicos e cientistas, amparados no aprendizado histórico, no amadurecimento crítico e nas novas possibilidades tecnológicas buscam construir uma nova alternativa para o trabalho, uma Economia Solidária. Busca-se um novo mundo de relações trabalhistas em que seja possível acreditar no amor em vez do medo; na democracia e autogestão em vez da opressão; na cooperação em vez da concorrência; na integração em vez da exclusão social; em sustentabilidade em vez de degradação; em trabalho digno, livre e solidário em vez da exploração da força de trabalho (SILVA, 2011, [n.p.]).

Sendo assim, à medida que o Estado se isenta da responsabilidade sobre políticas sociais, sobre a desigualdade e sobre os elevados índices de desemprego - delegando essas responsabilidades à iniciativa privada -, o movimento de Economia Solidária, até então apagado da perspectiva social, volta a aparecer como uma alternativa às problemáticas sistêmicas impostas pelo capitalismo.

No que diz respeito à reflexão e análise deste artigo, considera-se que o trabalho feito pela ITCP/Unicamp, junto aos EES incubados, propõe uma alternativa à exploração do trabalho capitalista em sua expressão neoliberal, considerando a intersecção das desigualdades de gênero, raça e classe. A seguir, abordar-se-á o contexto sócio-histórico em que as ITCPs foram fundadas, assim como seus princípios e metodologias, a fim de compor argumentos que evidenciem a importância de práticas extensionistas comunitárias, comprometidas com transformações sociais para e com as classes populares.

$* * *$

Em relação ao Ensino Superior, o desenvolvimento do capitalismo em sua expressão neoliberal acarretou um processo de desconstrução de pressupostos construídos ao longo do período de redemocratização. Sendo assim, no período que sucedeu à Ditadura Militar houve um esforço das Instituições de Ensino Superior (IES) para adotar medidas que prezassem pela integração do ensino, da pesquisa e da extensão, de modo a destituir o caráter classista das IES, o que foi sendo desestruturado pelo avanço neoliberal, especialmente pelo governo de Fernando Henrique Cardoso ${ }^{7}$. Tal desconstrução, nas palavras de Minto (2011), é decorrente de dois aspectos:

O primeiro, voltado para distanciar as IES de qualquer possibilidade de intervenção social crítica, vinculada a projetos de afirmação nacional, de autonomia e soberania frente aos países capitalistas centrais, razão pela qual era preciso atingi-la naquilo que de mais subversivo estava inscrito em seu potencial institucional: a lógica da integração ensino, pesquisa e extensão e da autonomia universitária. [...] O segundo fator era fundamentalmente econômico: para ser lucrativo, o ensino superior tem de se organizar de formas mais "flexíveis", mais afetas ao "mercado", não compatíveis com aquela universidade da Reforma de 1968 e, menos ainda, com a CF [Constituição Federal] /1988. (MINTO, 2011, p. 238 apud FRAGA, 2012, p. 58).

\footnotetext{
7 Sobre as atividades das IES, especialmente a prática extensionista, no período de redemocratização, ver FRAGA (2012).
} 
É possível inferir, com base em Minto, que a política econômica neoliberal reforçou o caráter classista das IESs, configurando um retrocesso durante os processos encaminhados durante a redemocratização. As desconstruções supracitadas afetaram as IES como um todo, mas especialmente as universidades públicas. Tratando-se das atividades extensionistas, o caráter assistencialista da prática, o qual configurou a extensão universitária durante os anos 1990, rompeu com a tendência de engajamento e articulação com a comunidade, com os grupos populares e com os movimentos sociais a que a extensão se predispunha durante o período da redemocratização. Assim, durante o governo FHC, a prática extensionista-assistencialista-mercantil tornou-se irrelevante à transformação social ${ }^{8}$.

Baseado no pressuposto de flexibilização das relações de trabalho, o neoliberalismo engendrou um intenso processo de precarização, o qual culminou em uma onda de desemprego que atingiu especialmente os grupos populares durante o período. Em um país em que nunca houve pleno emprego e, especialmente, na década de 1990, "o desemprego tornou-se a maior preocupação do brasileiro [...]. E com o desemprego veio a pobreza e a fome" (SINGER, 2000, p. 1 apud FRAGA, 2012, p. 79).

É nesse contexto de precarização do trabalho e de marginalização dos grupos populares que as Incubadoras Tecnológicas de Cooperativas Populares (ITCPs) surgem. Segundo Fraga, as ITCPs "surgem a partir de 1995, em uma conjuntura bastante particular do nosso país, quando parte da extensão universitária, diante de um contexto de altos índices de desemprego, se volta para o mundo do trabalho" (FRAGA, 2012, p. 3).

Por definição, a sigla ITCP significa, segundo Parra:

\begin{abstract}
Chamam-se incubadoras porque assim como nas maternidades, tem como objetivo criar um ambiente favorável para o autodesenvolvimento dos grupos assessorados. Combinando uma ação externa com as capacidades internas do próprio grupo. São Tecnológicas pela sua proposta de fornecer não só uma metodologia de intervenções adequada e em contínuo processo de aprimoramento, como também as melhores técnicas referentes à área de atuação da futura cooperativa. A palavra Cooperativas define uma opção de trabalho coletivo como forma de organização social que pode proporcionar maiores chances de inserção econômica. Acrescentaram ainda o adjetivo Populares especificando o público prioritário destes projetos. Mas o que é popular senão à exclusão social, ou ainda um eufemismo para a pobreza? (PARRA, 1999, p. 159 apud DA COSTA, 2018, p. 151).
\end{abstract}

Na Unicamp, a ITCP foi fundada como um programa de extensão universitária em 2001 cujo intuito é promover a geração de trabalho e de renda nos EES incubados. Vinculada à Pró-Reitoria de Extensão e Cultura (ProEC), a instituição fundamenta-se nos princípios da Educação Popular, da Autogestão, da Economia Solidária e da Tecnologia Social ${ }^{9}$. Assim, com base nesses princípios, a ITCP pretende fomentar a construção coletiva de uma concepção de realidade que parta da experiência vivida dos grupos incubados e promova a autonomia e a emancipação destes ${ }^{10}$.

O fato de os grupos populares parceiros da ITCP/Unicamp serem compostos na maioria por mulheres não brancas é um dado relevante quando analisado do ponto de vista social. É sabido que as mulheres negras estão em maior situação de vulnerabilidade social. A sociedade

\footnotetext{
Ibidem.

9 Ver mais sobre Autogestão, Economia Solidária e Tecnologia Social no contexto da ITCP/Unicamp em: ITCP (2011) e ITCP (2009).

${ }^{10}$ Ver metodologias de incubação em: ITCP (2009).
} 
brasileira, que se funda nas mazelas do racismo estrutura ${ }^{11}$ e do patriarcado, coloca as mulheres negras na base da pirâmide social, de modo que configuram o grupo de pessoas que compõem os indicadores de informalidade e de precarização do trabalho. Assim, pode-se afirmar que o processo de precarização acarreta a feminização da pobreza (ONU, 1995). Sendo assim, esse dado embasa a atuação das educadoras, que precisam olhar a realidade dos grupos incubados de forma sensível e ao mesmo tempo analítica, a fim de entender os processos das dinâmicas sociais pautados pela desigualdade de raça e gênero que ocorrem nos EES, de modo a trazer à tona e trabalhar essas temáticas.

É preciso construir uma alternativa à governança neoliberal. A Economia Solidária, diferentemente da economia capitalista, que se expressa nos dias de hoje pelo empreendedorismo, propõe a ação coletiva que parta da cultura e das demandas das classes populares, especialmente das mulheres negras. Não é incomum que, ao longo dos processos de crise social e econômica e por que não dizer, de crise ética -, diversos grupos populares tenham emergido reivindicando justiça social por meio da Economia Solidária e de práticas autogestionárias.

Contudo, deve-se ressaltar que a literatura acerca do tema demonstra que o debate sobre Economia Solidária ainda parte de referenciais que se pretendem universais, isto é, masculinos e brancos. A seção a seguir pretende apresentar essa problemática e desenvolver possíveis articulações entre o debate sobre a interseccionalidade e a Economia Solidária.

\section{ABORDAGEM INTERSECCIONAL SOBRE A ECONOMIA SOLIDÁRIA}

Na sociedade machista As oportunidades são racistas São dois pontos a menos pra mim É dificil jogar quando as regras Servem pra decretar o meu fim

(TÁSSIA REIS, Da Lama $\mid$ Afrontamento, 2016)

O mercado de trabalho no Brasil se estruturou por marcantes desigualdades, sobretudo de gênero e raça. No decorrer da história, principalmente no processo pós-abolição da escravidão, no que tange à inserção de mulheres negras no mercado de trabalho por meio de políticas do Estado, houve falhas institucionais e estruturais que marcaram a omissão dos setores público e privado no combate às desigualdades de gênero e raça. Esse processo culminou em sobreposições de diversas vulnerabilidades e criou barreiras complementares que impediram o acesso de determinados grupos e indivíduos ao trabalho formal:

[...] Esse processo foi marcado tanto por uma ausência de políticas públicas em favor dos ex-escravos e à população negra livre, como pela implementação de iniciativas que contribuíram para que o horizonte de integração dos ex-escravos ficasse restrito às posições subalternas da sociedade (THEODORO, 2008, p. 33).

No processo pós-abolição, determinadas leis e políticas públicas, somadas ao processo de industrialização tardia, foram determinantes para que se consolidasse o mercado informal no país. O movimento de analisar os processos sócio-históricos se faz necessário para que se compreendam as múltiplas faces que forjaram as condições de trabalho da população brasileira.

${ }^{11}$ Ver sobre racismo estrutural em ALMEIDA, Silvio de. Racismo estrutural. São Paulo: Pólen, 2019. 
A informalidade é a condição de quase metade da população ocupada nas regiões metropolitanas brasileiras, quando se considera a situação de desproteção social, tanto no que diz respeito à cobertura da legislação trabalhista e previdenciária, como no que tange ao abrigo da negociação coletiva. Esse fenômeno não pode ser entendido sem se considerar o processo histórico de formação do mercado de trabalho nacional e as tendências recentes da organização da produção, da estrutura produtiva e das relações de trabalho no Brasil (DIEESE, 2012a, p. 166).

A produção historiográfica sobre a temática do trabalho no Brasil é dividida em dois momentos: antes e após a escravidão, em 13 de maio de 1888. Entretanto, em ambos os momentos, pouco se olhou para os trabalhadores negros como potência produtiva, principalmente após a abolição, quando emergiu uma nova organização da sociedade brasileira centralizada no trabalho assalariado. Segundo as palavras de Ynaê Lopes dos Santos quanto aos estudos e referências sobre trabalho após a abolição, "é como se a questão negra simplesmente sumisse" (LABUTA, 2020), movimento impelido pelo racismo estrutural.

A falta de um olhar mais sensível pelas lentes da historiografia afetou diretamente as outras áreas das ciências humanas no decorrer dos anos, perpassando pela educação básica de História e as produções científicas no ensino superior até a formulação de políticas públicas. Segundo Santos e Antonio Sérgio Guimarães (LABUTA, 2020), a escolha por entender o mundo do trabalho somente pela perspectiva do trabalho assalariado promove a exclusão da escravização e marginaliza o trabalho realizado por pessoas negras escravizadas e livres. Considerar os sujeitos negros como atores do processo de desenvolvimento econômico, além de ampliar as fontes documentais acerca da história do trabalho, também propicia novos olhares aos homens e mulheres negros e negras.

No sentido contrário a um projeto de desenvolvimento econômico que atenuasse os problemas socioeconômicos da época, as políticas públicas implementadas pelo Estado no processo pré e pós-abolição acabaram reforçando as desigualdades já existentes. Essas políticas desenhavam o que se coloca aqui como três movimentos. O primeiro é a abolição em 1888 , que foi realizada por meio de pressões internas dos abolicionistas e externas da Inglaterra sem haver políticas públicas direcionadas para a inserção da população negra no mercado de trabalho.

O segundo momento foi um movimento do Estado, por meio da implementação de políticas de imigração, na qual se instituiu um decreto para livre entrada de imigrantes - exceto se estes fossem da África ou Ásia.

As políticas públicas voltadas à promoção da imigração vieram a acentuar esse quadro de desigualdades regionais [...]. O período mais intenso do processo de imigração foi o que ocorreu nos anos que se seguiram à abolição, 1888 a 1900, quando se observa a entrada de 1,5 milhão de imigrantes, em sua maior parte italianos [...] (THEODORO, 2008, p. 35).

O terceiro movimento induzia o apagamento dos conflitos raciais, estruturando o mito da democracia racial e sistematizado pela primeira vez, segundo Florestan Fernandes, na obra Casa-Grande \& Senzala, de Gilberto Freyre, em 1933. Conforme colocado pelo DIEESE, "durante parte do século XX, foi propagada a ideia de que a sociedade brasileira vivia uma situação de paraíso ou democracia racial, sem que nela fossem observados grandes conflitos raciais e discriminação como os que ocorriam em outras nações" (2012, p. 199). Assim se apagam os efeitos da escravidão na população, de modo que o Estado pode se isentar de construir políticas voltadas a esse grupo. Além disso, faz coro a ideia da meritocracia, típica do 
contexto neoliberal atual, na medida em que coloca que todos têm as mesmas possibilidades de ascender socialmente.

Desse modo, entre meados do século XIX e do século XX, o trabalho escravo foi substituído pelo trabalho livre por meio dos rastros de um imaginário racista somado às políticas discriminatórias:

O país reserva, como consequência, papéis e oportunidades sociais diferenciados para os diversos grupos étnicos e raciais que nele vivem. Além disso, a desigualdade entre os sexos, que atravessa, em diagonal, toda a sociedade brasileira, intensifica as diferenciações já existentes (DIEESE, 2012b, p. 199).

As desigualdades raciais recorrentes por séculos desenham a estrutura da sociedade. Entretanto, outros marcadores também cruzam o espectro das relações sociais. Para além das disparidades sócio-históricas entre as raças, diversas análises dos estudos sociais apontam as discriminações que perpassam o gênero como barreira impeditiva do acesso aos direitos, especialmente ligados ao trabalho.

A mulher negra vivencia maior dificuldade de se inserir no mercado de trabalho, está mais presente em postos de trabalho vulneráveis e também ganha menos, quando se compara o rendimento das negras e dos negros assalariados em relação ao rendimento médio hora do homem assalariado não negro (DIEESE, 2012, p. 200).

Em meio às crescentes taxas de desemprego no mundo, que atingem principalmente as mulheres, é importante fazer um recorte de gênero quando se pensa em crises cíclicas na economia e, consequentemente, na (in)capacidade de se gerar empregos no país. Segundo dados da Síntese de Indicadores Sociais: uma análise das condições de vida da população brasileira, de 2019, feita pelo IBGE, as mulheres e a população preta ou parda têm os maiores índices de desocupação no país, devido a uma estrutura social marcada pela discriminação de gênero e raça. Na Declaração e Plataforma de Ação da IV Conferência Mundial Sobre a Mulher (ONU, 1995), a feminização da pobreza foi colocada como uma problemática mundial que precisa ser combatida por meio de políticas de enfrentamento à pobreza.

A problemática da feminização da pobreza manifesta-se como uma das consequências da cultura patriarcal no mercado de trabalho, evidenciando que nos ciclos de crises econômicas existem grupos sociais que vão sofrer os impactos de forma mais violenta e com menor viabilidade de resiliência. Nesse sentido, em que historicamente foi estruturada a divisão sexual do trabalho (HIRATA; KERGOAT, 2007), na qual homens e mulheres exercem funções diferentes, é importante entender os porquês: além dessas diferenças, também existem hierarquias.

Ao refletir sobre a feminização da pobreza e a divisão sexual do trabalho enquanto fenômenos que empurram as mulheres para a base mais explorada da sociedade, solidificando as desigualdades e hierarquias entre homens e mulheres, faz-se necessário compreender as opressões como uma teia complexa. Assim, pensar nelas de forma isolada acaba limitando a análise, como se fossem peças separadas, quando a ideia aqui é, também, entender como essas peças se integram.

Segundo Kimberlé W. Crenshaw, intelectual norte-americana defensora dos direitos civis e uma das principais estudiosas da teoria crítica da raça, após as conferências de Viena (1992) e de Pequim (1995) iniciou um movimento de mulheres que compreendem elementos relevantes no que tange aos Direitos Humanos e aos direitos das mulheres. Quando se vivencia as violações dos direitos humanos, o que também ocorre com homens, deve-se haver proteção de forma simétrica e similar. Por outro lado, quando as mulheres sofrem violações diferenciadas 
ligadas ao gênero elas também devem ser protegidas com aparatos que deem conta das opressões com esse recorte.

Assim, na concepção de Crenshaw, essa análise também se aplica à discriminação racial, uma vez que quando esta estava na esfera da participação política, a tendência era que fosse reconhecida como violação dos direitos humanos. Entretanto, quando vivenciada como uma discriminação implícita, como outras formas de segregação, a disputa era fazer com que essas opressões diferenciadas pelas quais pessoas negras eram atravessadas fossem consideradas à luz de um entendimento mais amplo dos direitos humanos.

\begin{abstract}
Assim, tanto as questões de gênero como as raciais têm lidado com a diferença. O desafio é incorporar a questão de gênero à prática dos direitos humanos e a questão racial ao gênero. Isso significa que precisamos compreender que homens e mulheres podem experimentar situações de racismo de maneiras especificamente relacionadas ao seu gênero. As mulheres devem ser protegidas quando são vítimas de discriminação racial, da mesma maneira que os homens, e devem ser protegidas quando sofrem discriminação de gênero/racial de maneiras diferentes (CRENSHAW, 2004, p. 9).
\end{abstract}

Uma problemática em colocar as discriminações somente como categorias paralelas de opressão é que se separam as discriminações de gênero às mulheres; as raciais, às pessoas negras; as de classes, somente aos pobres. A interseccionalidade ${ }^{12}$, termo cunhado e sistematizado pela primeira vez por Crenshaw em 1989, é uma categoria de análise que desconstrói a ideia de que as relações se dão entre grupos distintos, quando, muitas vezes, são grupos e opressões sobrepostas. Conforme se pode observar na Figura 1, há uma sobreposição entre mulheres às pessoas negras, com pessoas pobres somadas às pessoas sulistas, ilustrando o conceito de interseccionalidade.

\title{
FIGURA 1 - DIAGRAMA DA INTERSECCIONALIDADE
}

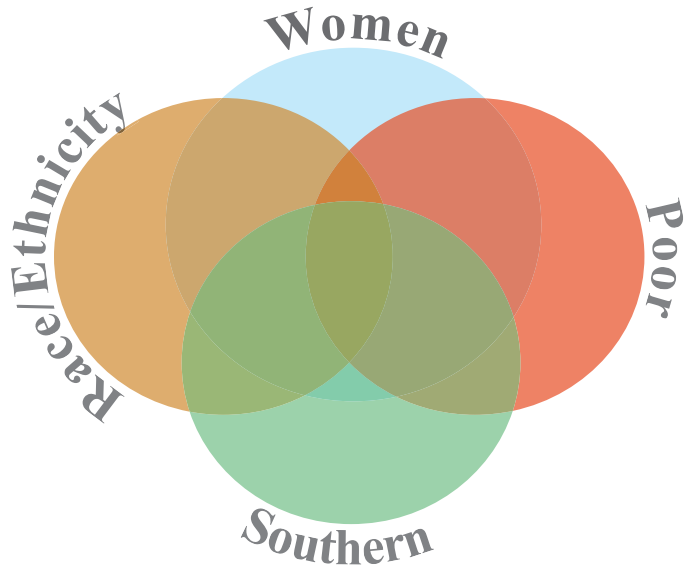

$$
\begin{gathered}
\text { Women }=\text { Mulheres } \\
\text { Poor }=\text { Pobres } \\
\text { Southern }=\text { Sulistas } \\
\text { Race/Ethnicity }=\text { Raça/Etnicidade }
\end{gathered}
$$

Fonte: Crenshaw, 2004, p. 10.

A Figura elucida algumas categorias de forma sobreposta, na qual as opressões, em determinadas experiências, não se separam, mas se intercruzam. Nas experiências da vida, essa

\footnotetext{
${ }^{12}$ Ver mais sobre interseccionalidade em CRENSHAW (1989).
} 
sobreposição é nítida quando se é mulher, negra, periférica, lésbica e mais outras categorias de opressão que poderiam compor essa imagem. A reflexão-referência se estende ao campo do trabalho, uma vez que as mulheres negras ocupam índices desiguais no mercado de trabalho.

Considerando essa análise na perspectiva das relações de trabalho, no Brasil, como alternativa ao mercado competitivo e excludente, os grupos populares da Economia Solidária são formados muitas vezes por trabalhadores pobres e não brancos, com baixa escolaridade e nível de formação técnica. Apesar dessa perceptível característica de composição, há na bibliografia sobre Economia Solidária uma grave ausência de raça como eixo de análise, evidenciando um descompasso com a realidade das trabalhadoras e dos trabalhadores brasileiros.

No que se refere às mulheres dos empreendimentos parceiros, um dos desafios enfrentados está relacionado às diversas jornadas de trabalho que elas precisam assumir para além do trabalho na produção, desde a limpeza e manutenção do espaço de trabalho até as tarefas para com a família. A naturalização do trabalho de cuidado como de responsabilidade da mulher faz com que ocorra uma sobrecarga de funções, de maneira a influenciar a quantidade de energia a ser despendida na produção:

\begin{abstract}
Na última visita de Angela Davis à Bahia, na ocasião da conferência proferida em 25 de julho de 2017, Angela afirmou que "quando a vida das mulheres negras importar, teremos a certeza de que todas as vidas importam"'13. Esta citação revela o modo como as mulheres negras, estando na base da pirâmide social, vivenciam o descaso do poder público com as populações negras e pobres, que vão desde o acesso à água, saúde, moradia, educação e trabalho, ao tempo em que aponta para a permanência de um sistema estruturado em bases patriarcais, no qual a socialização de gênero ainda atribui às mulheres a responsabilidade pela manutenção da família e $\mathrm{o}$ cuidado com a prole. A sobrecarga de responsabilidades associada ao racismo e às representações estereotipadas sobre o corpo feminino negro tem causado inúmeros prejuízos às mulheres negras, que têm buscado estratégias coletivas como um modo de enfrentamento às desigualdades (FIGUEREDO, 2018, p. 1082-1083).
\end{abstract}

Em relação ao trabalho da ITCP/Unicamp frente aos empreendimentos solidários, o olhar interseccional se faz necessário como metodologia de análise e intervenção, uma vez que os grupos são formados majoritariamente por mulheres-negras-pobres (gênero, raça e classe), categorias estabelecidas nos três grupos incubados atualmente. Entretanto, outras opressões se fazem presentes e atravessam as vivências nos trabalhos (e nas vidas) dos grupos.

As experiências de Economia Solidária no território urbano, periférico ou não, e rural têm respectivas particularidades, assim como cada EES é composto por mulheres e alguns homens com diferentes idades, orientações sexuais, etnias, entre outros marcadores.

\title{
4. RELATOS DE EXPERIÊNCIA NOS EES -ITCP/UNICAMP
}

\author{
Há aqueles que lutam um dia; e por isso são muito bons; \\ Há aqueles que lutam muitos dias; e por isso são muito bons; \\ Há aqueles que lutam anos; e são melhores ainda; \\ Porém há aqueles que lutam toda a vida; esses são os imprescindiveis.
}

(BRECHT, Bertold | "Os que lutam”)

\footnotetext{
${ }^{13}$ Discurso de Angela Davis durante a conferência de abertura da Escola de Pensamento Feminista Negro, em 17 de julho de 2017, na cidade de Cachoeira-BA.
} 


\section{Horta das Margaridas (Jardim Bassoli, Campinas-SP) - Equipe Corpo}

A experiência no Jardim Bassoli, que é um condomínio do Programa Minha Casa, Minha Vida (PMCMV), é caracterizada por duas fases. Primeiro houve o oferecimento de um curso intitulado "Mulheres na Economia Solidária", por meio de uma parceria entre a ITCP/Unicamp e o Centro de Tecnologia (CTI) Renato Archer, de Campinas. O curso teve a duração de dois meses com encontros semanais a fim de discutir temáticas como Economia Solidária, Finanças Solidárias, Autogestão, Economia Feminista, Planejamento Produtivo, Territorialidade e Avaliação Coletiva.

Segundo OÃO (2012), o Jardim Bassoli é o empreendimento do PMCMV mais distante do centro da cidade. Localizado a aproximadamente $20 \mathrm{~km}$ do centro de Campinas, o condomínio foi construído na franja do perímetro urbano, onde os equipamentos sociais são mais escassos e a falta de infraestrutura é mais marcante. O bairro está inserido na extrema periferia de Campinas, cidade em que se pratica a maior tarifa de ônibus do país ${ }^{14}$. Assim, a distância geográfica se torna uma barreira na mobilização pela distância, somada ao alto preço da tarifa.

No início do curso, identificou-se que seriam necessárias algumas (re)adaptações para continuidade da formação e aderência das mulheres participantes. $\mathrm{O}$ espaço físico onde o curso foi ministrado se localizava em um salão de festas de um condomínio com estrutura bastante precária - havendo buracos nas paredes que permitiam entrada excessiva de luz, chuva e/ou interferências sonoras. Além disso, identificou-se que a maioria das mulheres inscritas eram mães e avós e, desse modo, o espaço da ciranda foi fundamental para a permanência das mulheres no curso. Com isso, o curso e a ciranda aconteceram no mesmo espaço físico e ao mesmo tempo, fazendo com que houvesse barulho mútuo.

Ao final do curso, com a entrega de trinta certificados, as mulheres participantes demonstraram interesse em organizar algum empreendimento. As opções mapeadas eram 1) cooperativa de artesanato e 2) horta comunitária. Algumas participantes se organizaram e conseguiram um terreno na escola onde seus filhos e filhas estudam, tornando assim a segunda opção de empreendimento mais viável.

Desse modo, a experiência caminhou para uma segunda fase de incubação, pois o empreendimento não está formalizado e, atualmente, apenas um pequeno número de mulheres participa do projeto - fenômeno decorrente das intersecções de opressões. O objetivo inicial era formar uma cooperativa de mulheres, por meio de uma horta urbana e comunitária, a fim de consumir e comercializar hortaliças produzidas de forma agroecológica.

No decorrer do projeto, tem sido perceptível que as barreiras encontradas pelas mulheres envolvidas são, na maioria, consequência das questões de gênero, raça, classe, território, entre outras categorias de opressão. Essas barreiras, intrínsecas em suas vivências, muitas vezes convergem para a rotina de trabalho e produção. Ou seja, o trabalho parte dessa configuração e ignorar isso impossibilitaria o desenvolvimento do projeto de modo participativo. Não se conscientizar sobre as opressões que perpassam as experiências das mulheres no ambiente de trabalho seria o mesmo que omitir suas vivências e minar o engajamento da prática autogestionária.

O comprometimento com a política feminista e com a luta pela libertação negra significa que tenho que ser capaz de confrontar as questões de raça e gênero dentro de um contexto negro, proporcionando respostas significativas para perguntas problemáticas e meios acessíveis e apropriados para comunicar essas pessoas (HOOKS, p. 152, 2013).

\footnotetext{
${ }^{14}$ Ver notícia sobre as tarifas de Campinas e capitais em: https:/g1.globo.com/sp/campinas-regiao/ noticia/2019/07/08/campinas-tem-tarifa-de-onibus-mais-cara-que-todas-as-capitais-brasileiras-valor-e-r-495. ghtml. Acesso em: 28 nov. 2020.
} 
Muitas dessas mulheres relataram que se viam obrigadas a mentir sobre o bairro em que moram (ou omiti-lo) para assim, talvez, obterem um emprego. Entretanto, ainda assim, muitas enfrentam a barreira que exclui mulheres mães ou (também) a barreira racista que marginaliza mulheres negras por conta de seus cabelos crespos e/ou pele escura. Relatos sobre essas vivências estão presentes constantemente em ambas as fases - construção do curso e incubação.

Assim, o início do projeto foi marcado justamente por diálogos voltados para a Economia Solidária como alternativa, justamente porque a economia capitalista se estrutura de forma excludente - extinguindo justamente pessoas negras, mulheres, pobres. Desde o curso, as mulheres relataram dificuldades em acessar um emprego formal pelo fato de serem moradoras do Jardim Bassoli, sendo excluídas de oportunidades de emprego por estarem na periferia, logo, "longe do centro". Ou seja, o território coloca essas mulheres entre duas barreiras, a geográfica, que as afasta dos centros urbanos, e a imaginária, que está presente no imaginário dos possíveis patrões - que excluem as mulheres dos postos de trabalhos formais por serem residentes de um bairro periférico.

\section{Cooperativa Santa Genebra (Santa Genebra, Campinas-SP) - Equipe Redes}

A reciclagem evita uma série de danos causados pelos processos produtivos, como "perda de recursos madeireiros e não madeireiros, danos ao ciclo hidrológico, perda de biodiversidade, impactos sobre a saúde ocupacional e danos à saúde humana oriundos de emissões atmosféricas" (IPEA, 2017), apresentando uma série de benefícios ambientais. Além disso, se constitui como uma política de trabalho e renda para as pessoas que sobrevivem da coleta, os catadores (IPEA, 2017). No setor de pessoas excluídas do mercado de trabalho tradicional, essa categoria retira do que é considerado lixo suas condições para sobreviver, sofrendo preconceitos devido à natureza dessa atividade (IPEA, 2017).

A história de luta dos catadores e catadoras é marcada pela fundação do Movimento Nacional dos Catadores de Materiais Recicláveis (MNCR), em 2001, pelo reconhecimento da profissão de catador, pela conquista da possibilidade de contratação das cooperativas de catadores pelos municípios sem licitação, pela instituição da Coleta Seletiva Solidária em diversas cidades do país, entre outras conquistas (SILVA, 2014). Isso mostra o potencial da ação coletiva dessa categoria.

Ainda assim, há diversos obstáculos ao desenvolvimento do setor. Os catadores competem com a terceirização e o setor privado, sendo que $70 \%$ das despesas com resíduos sólidos vai para empresas privadas (OLIVEIRA, 2011). Além disso, apenas 13\% dos resíduos urbanos gerados são destinados para a reciclagem (IPEA, 2017), mostrando a precariedade da política ambiental no Brasil e a exclusão do catador no processo de gestão de resíduos sólidos. Com isso, se mantêm tanto as condições de desigualdade social e econômica das pessoas que compõem essa categoria quanto a marginalização dessa atividade.

Em Campinas, por volta dos anos 2000, foram instituídas diversas políticas públicas de fortalecimento de cooperativas, especialmente as de catadores. No entanto, elas estão sujeitas às alterações do governo municipal (ITCP/Unicamp, 2013). Atualmente, a Coleta Seletiva na cidade é feita por meio do Consórcio Renova Ambienta $1^{15}$. Por meio desse contrato, a prefeitura terceiriza o trabalho de limpeza urbana. A maior parte das cooperativas está incluída nesse processo de coleta como parceira da Prefeitura, mas não é contratada. Todo o material coletado

\footnotetext{
15 Ver mais em: http://www.mbengenharia.com/conteudo/noticias.php?cod=94. Acesso em: 29 ago. 2020.
} 
pelo Serviço de Coleta Seletiva é destinado às cooperativas listadas como parceiras ${ }^{16}$, para que façam a separação e a venda de materiais. Além disso, há a intenção de formar uma Parceria Público-Privada ${ }^{17}$ para a gestão de resíduos da cidade pelos próximos 30 anos. Assim, apesar de prestarem um serviço ambiental para a cidade por meio da triagem, venda e coleta de materiais recicláveis, as cooperativas não são contratadas pelo município e não há intenção do poder público em mudar esse quadro.

Com isso, a primeira dificuldade enfrentada pelas cooperativas é que elas contam apenas com a arrecadação da venda de materiais para fazer a manutenção do espaço e dos equipamentos de triagem, arcar com as despesas do barracão e dividir as sobras entre os cooperados. Logo, é comum a dificuldade de fechar as contas e o desgaste dos equipamentos. Outra dificuldade imposta por esse funcionamento da coleta seletiva na cidade é a qualidade com que o material chega às cooperativas. O caminhão da coleta não cobre a cidade toda, apenas algumas regiões, logo não atinge o potencial máximo do quanto pode ser recolhido e reciclado. Outro ponto é que não há um programa eficiente de educação ambiental para a população. Assim, parte do material chega às cooperativas com sobras do que é considerado lixo. Diante disso, a discussão sobre a organização do trabalho e a gestão da cooperativa são questões que ficam em segundo plano na visão dos cooperados.

A ITCP/Unicamp, desde sua fundação, esteve intimamente ligada aos programas de incentivo a processos cooperativistas na cidade, sendo inclusive reconhecida pelo município pelo Decreto n. ${ }^{\circ}$ 14.265/03, de 2003. Atualmente, a ITCP incuba a Cooperativa Santa Genebra, fundada em 2006 por um grupo de trabalhadores aposentados e que engloba catadores de materiais recicláveis. O trabalho com essa cooperativa começou em 2018. O número de cooperados variou entre 8 e 12 durante o período de incubação. Um núcleo fixo de cerca de cinco membros se manteve, sendo constante a rotatividade de pessoas fora desse grupo. Mesmo com as variações, a cooperativa geralmente é composta majoritariamente por mulheres negras. Logo, além de lidar com o estigma que envolve profissionais que lidam com o lixo, esse grupo ainda lida com questões de gênero, raça e classe.

Apesar de a cooperativa estar consolidada e regularizada há bastante tempo, ainda apresenta dificuldades em implantar um modelo autogestionário. Por se tratar de uma profissão marginalizada, os catadores tendem a abandoná-la ao conseguir uma oportunidade no mercado formal (IPEA, 2017). Já que não há uma perspectiva em longo prazo de permanecer nessa função, o reconhecimento enquanto categoria e a identificação com a cooperativa é dificultado. Isso se torna um desafio para a incubadora discutir cooperativismo e estabelecer vínculos com os cooperados, uma vez que a composição da cooperativa muda frequentemente.

Portanto, para esse grupo existe uma emergência pela obtenção de renda que orienta a opção por esse trabalho, e ela precisa ser discutida quando se busca desenvolver os princípios de cooperativismo e autogestão com o grupo. A fim de lidar com a questão da qualidade e da quantidade de material que chega à Santa Genebra, a ITCP trabalhou em conjunto com a cooperativa em um edital de financiamento para aplicar a coleta seletiva solidária. Trata-se de uma tecnologia social na qual a cooperativa faz a coleta porta a porta no território ao seu redor, dialogando com os moradores e comerciantes para incentivá-los a fazer a separação do lixo e destinar os recicláveis para a cooperativa. Isso também dá visibilidade para o trabalho do catador e sua importância tanto na limpeza da cidade quanto na discussão sobre questões

\footnotetext{
${ }^{16}$ Ver listagem de cooperativas parceiras em: http://www.campinas.sp.gov.br/governo/servicos-publicos/dlu/ programa.php. Acesso em: 29 ago. 2020.

${ }^{17}$ Sobre a "PPP do Lixo", ver: https://www.pppdolixo.minhacampinas.org.br/\#block-10353. Acesso em: 29 ago. 2020.
} 
ambientais. Também melhora a qualidade do material, na medida em que orienta as pessoas sobre como fazer a separação do lixo.

A execução desse edital evidenciou que há também muita resistência entre a população e os comércios em aderir à coleta seletiva, uma vez que, apesar de haver certo conhecimento sobre a separação do lixo, foram poucos os que se dispuseram a firmar um compromisso em destinar seus resíduos para a cooperativa. Foi percebido que o estigma em relação aos catadores dificulta uma articulação para apoiar esse setor. Para além da pauta ambiental, o trabalho do catador também tem um papel social para aqueles que compõem a categoria, dando-lhes uma oportunidade de trabalho e renda. Ainda assim, tem sido desafiador para a cooperativa e para a Incubadora mobilizar a população local em torno dessas pautas, o que se agrava pela falta de apoio do poder público.

Diante da falta de incentivo por parte de políticas públicas e da condição social em que estão os membros das cooperativas, o tempo disponível para a construção de um empreendimento cooperativo é limitado (IPEA, 2017). Todo o tempo empregado em discutir sobre a organização da cooperativa e em realizar reuniões e assembleias é um período que os cooperados deixam de triar. A triagem é a etapa na qual é separada a parte dos resíduos que pode ser reciclada e, portanto, vendida. Quanto mais se consegue triar em um dia, maior é a retirada do dia de trabalho. Logo, é de onde vem a renda dos cooperados. Durante as incubações, essa preocupação por parte deles foi colocada com frequência. Portanto, inserir a discussão sobre a autogestão na cooperativa passa por quebrar com a lógica de produtividade e lidar com questões que são emergenciais para esse grupo.

No que se refere à organização do trabalho na Santa Genebra, foi percebido que as tarefas se dividem da seguinte forma: gestão, venda dos materiais, coleta, triagem, limpeza do local, operação de equipamentos (prensa e empilhadeira). Existem níveis diferentes de participação nas atividades da cooperativa, e uma diferença é o planejamento do trabalho e sua execução, a qual está centralizada na presidência e em alguns poucos cooperados. Assim, por mais que existam alguns mecanismos de autogestão na cooperativa, como as assembleias e a divisão das sobras, nota-se algum grau de hierarquização.

As mulheres são maioria nos postos de gestão das cooperativas de reciclagem (PEREIRA; GOES, 2016, apud VARGAS, 2019) e isso se aplica na Santa Genebra. Ainda assim, a divisão do trabalho apresenta uma marcação de gênero. O cuidado com o espaço e as tarefas de limpeza são função apenas das mulheres, enquanto os homens fazem a operação dos equipamentos. Além disso, embora a triagem seja uma tarefa de todos, as mulheres são as que passam mais tempo exercendo essa função, enquanto os homens são responsáveis por atividades relacionadas à força física. Apesar do cooperativismo possibilitar alguma autonomia financeira para as mulheres negras e pobres, esse espaço não está isento de reproduzir desigualdades.

Diante disso, é possível perceber que a dinâmica das cooperativas de catadores, em especial a de Santa Genebra, é complexa e contraditória. A profissão de catador ainda conta com o estigma de um grupo que lida com o lixo, e apesar de ser uma opção de geração de trabalho e renda, esse grupo permanece inserido em um setor marginalizado. No que se refere às questões de gênero e raça, mulheres negras e pobres não deixam de ter sua atuação associada a atividades que reproduzem estigmas de gênero e raça. Ainda assim, elas se mostram conscientes de sua posição. Não apenas de sua condição de exclusão e de suas dificuldades, mas das suas potencialidades e de como sua articulação as fortalece. Apesar das dificuldades em inserir a autogestão e as questões de gênero e raça entre os integrantes da Santa Genebra, a potência e a necessidade do coletivo são reconhecidas por eles. 


\section{Coletivo de Produtoras Elizabeth Teixeira - Equipe Agricultura}

A estrutura agrária brasileira, cujo fundamento mais expressivo é a concentração fundiária, está profundamente associada à miséria da população rural brasileira (PRADO, 2000). Assim, a acentuada desigualdade social que acomete as populações rurais é justificada especialmente pelas precárias condições de manutenção da vida material e cultural. A interação entre as questões agrárias e agrícolas diz respeito especificamente à centralidade que pessoas submetidas a condições de acentuada desigualdade social desempenham na dinâmica social e econômica da produção agropecuária. Em outras palavras, apesar de considerar que a interação entre as questões agrárias e agrícolas está associada a uma heterogeneidade de sujeitos (trabalhadores rurais, grandes e pequenos proprietários rurais, empresários, entre outros), a questão agrária como um problema diz respeito especialmente àqueles à margem da sociedade, submetidos ao processo de expulsão e expropriação das terras ${ }^{18}$.

O Brasil é um dos países em que há maior desigualdade na distribuição de terras. Devese ressaltar que a aquisição de terras é um processo político e econômico intrínseco à história brasileira, o qual engendra uma relação de poder entre aqueles que são providos e desprovidos das propriedades rurais. Em outras palavras, a ocupação do território brasileiro pelas elites latifundiárias corresponde a um histórico de apropriação que remonta ao período colonial. "Toda ação das elites rurais sempre foi na contramão da lei" (OLIVEIRA apud CASTILHO, 2012, p. 60). Além disso, reitera-se que a concentração de terras é um dos fundamentos da violência no campo.

O Coletivo de Produtoras Elizabeth Teixeira se organiza no pré-assentamento Elizabeth Teixeira, localizado em Limeira-SP e vinculado ao Movimento dos Trabalhadores Sem Terra (MST). Trata-se de um território que pertence à União e vem sendo disputado entre os trabalhadores sem-terra, o poder público municipal e empresas privadas. Desde 2007, os SemTerra têm pressionado o Instituto Nacional de Colonização e Reforma Agrária (INCRA) pela regularização do assentamento, o que lhes garantiria maior acesso a direitos e ao exercício da cidadania. Isto é, devido à falta de regularização do território, somada à ausência de condições e de infraestrutura, que o poder público deveria promover, como saneamento básico, acesso à rede elétrica e mobilidade, as pré-assentadas e os pré-assentados se encontram em situação de grande vulnerabilidade social.

As instâncias governamentais de poder se fazem presentes para a repreensão e ausentes para assegurar acesso aos direitos e à infraestrutura, o que marginaliza profundamente as pessoas que vivem e trabalham nesse território. Essa ausência, de alguma forma, interfere no modo como as produtoras do coletivo e os companheiros pré-assentados veem a si mesmos e são vistos pelas outras pessoas, que é, geralmente, uma forma muito violenta. No entanto, dessas ausências e violências surge uma necessidade de se organizar, de cooperar e de desenvolver formas diferentes de lidar com o cotidiano. Das diferenças que são possíveis de observar, há uma relação mais sustentável de se alimentar, por exemplo, de gerir bens naturais, especialmente a água, e de consumir. Em outras palavras, a necessidade de organização, cooperação e desenvolvimento de formas alternativas às relações capitalistas têm sido uma oportunidade de ressignificar o espaço, mas também as próprias relações, como um espaço autogestionário, fundado no princípio da Economia Solidária.

Esse ímpeto possibilitou que o Coletivo de Produtoras Elizabeth Teixeira, constituído por seis mulheres, produzisse de forma sustentável e livre de veneno toneladas de alimentos a serem comercializados nos municípios de Limeira-SP e Campinas-SP. Atualmente, as produtoras

\footnotetext{
${ }^{18}$ Ver mais sobre questões agrárias e agrícolas em: PRADO (2000) e OLIVEIRA (1999) e (2018).
} 
organizam Grupos de Consumo Responsável em ambos os municípios e comercializam cerca de 400 cestas de alimentos por mês.

De certo modo, os movimentos sociais buscam corresponder às contradições a partir de formações que induzam uma mentalidade emancipadora que oriente a prática. Como equipe de incubação, avalia-se que se privilegiou a dedicação dos esforços às questões práticas, em vez de promover/incentivar formações sobre os princípios emancipadores que orientam a prática. Considera-se ainda, que há discussões relacionadas à prática autogestionária que dizem respeito à formação da subjetividade dos sujeitos, com base em suas experiências como sujeitos sociais (no caso das produtoras do coletivo: mulheres, agricultoras, em situação de pré-assentadas). A formação dessa subjetividade é, por vezes, muito dolorosa, porque diz respeito a processos de discriminação inerentes à organização social capitalista. No entanto, deve-se ressaltar que questões de raça e gênero não são exclusivamente subjetivas, mas compõem a materialidade das relações.

Deve-se considerar, portanto, que mesmo inseridos nas dinâmicas da Economia Solidária, os empreendimentos não estão isentos das contradições e dos estigmas que fundamentam as relações de trabalho no sistema capitalista, especialmente em sua expressão neoliberal.

\section{Desafios dos ESS no contexto da pandemia de Covid-19}

Durante a pandemia, a falta de políticas públicas voltadas para as populações mais vulneráveis aprofunda suas dificuldades de sobrevivência. Segundo o Núcleo de Operações e Inteligência em Saúde (NOIS), a distribuição geográfica e as desigualdades socioeconômicas resultam em maior mortalidade entre a população negra e pobre. No entanto, a solidariedade como estratégia de sobrevivência se mostra cada vez mais como uma saída.

A falta de uma estratégia política de combate e contenção da pandemia não fornece condições para que a população possa ficar em casa e manter o isolamento social. Apesar de esse ser o método mais recomendado por especialistas e o mais exitoso em países que conseguiram conter o vírus, não foi adotado ampla e profundamente pelo poder público no Brasil. Em Campinas-SP ${ }^{19}$, mesmo com o número elevado de casos, o funcionamento de boa parte das atividades comerciais, como shoppings, academias, bares etc., tem sido permitido desde julho de 2020. Com isso, a pressão para que a população mais vulnerável retorne ao trabalho para garantir seu sustento é grande. Deve-se ressaltar que as trabalhadoras e os trabalhadores dos empreendimentos incubados pela ITCP/Unicamp dependem inteiramente da renda gerada nos próprios EES; assim, as estratégias apresentadas pela Economia Solidária são fundamentais para manter a vida dessas pessoas.

No que diz respeito à atuação da Equipe Redes, apesar da autorização para as atividades comerciais, a coleta seletiva na cidade permanece suspensa. Sem isso, os resíduos gerados vão para o aterro, sobrecarregando esse destino. Além disso, os catadores ficam sem sua principal fonte de material, que vem do caminhão da coleta seletiva. As poucas garantias a que os cooperados tiveram acesso, que foram cestas básicas, foram fruto da mobilização da categoria na cidade. Para o Jardim Bassoli e o Elizabeth Teixeira, apesar de cada território e experiência terem suas particularidades, o afastamento do centro urbano tem grande impacto nesse período. Essa população já é atingida pela falta de água, saneamento e limpeza urbana. Com a pandemia, a falta de políticas públicas voltadas para os territórios é cada vez mais um

\footnotetext{
${ }^{19}$ Ver informações sobre a cidade de Campinas na pandemia em: https://covid-19.campinas.sp.gov.br/. Acesso em 30 ago. 2020.
} 
problema. Além disso, ambos os grupos são formados somente por mulheres, e a suspensão das aulas afetou diretamente o planejamento produtivo e a rotina do trabalho.

Diante disso, a solidariedade é estratégica. Segundo Stella Paterniani e Lauro Carvalho, em artigo publicado na plataforma Tricontinental ${ }^{20}$ : "O povo está inventando suas próprias formas de superar os desafios impostos pelo vírus e pelo Estado brasileiro, especialmente no que diz respeito à manutenção de renda, obtenção de alimentos e promoção da saúde e bem-estar" (2020, [n.p.]). No entanto, os autores estabelecem uma diferenciação entre a solidariedade S.A. e a solidariedade popular. A primeira parte de uma relação vertical que diferencia quem pode doar de quem só pode receber. Entre as grandes corporações, trata-se mais de uma ação para a propaganda do que para a solidariedade, estimulando o lucro das empresas no futuro. A segunda entende a solidariedade como uma relação entre todos os envolvidos, na qual todos têm algo a receber e a oferecer. Além disso, parte de uma relação orgânica e horizontal entre movimentos sociais, coletivos, associações de bairro e apoiadores.

Essa diferenciação tem impacto entre os grupos com os quais a ITCP trabalha. A solidariedade S.A. aproxima-se de uma prática assistencialista, uma expressão neoliberal da extensão. Para atuar com empreendimentos que tenham relação com o território, reflitam as necessidades do coletivo e sejam autoorganizados, as ações de solidariedade popular têm o potencial de fortalecer os grupos, uma vez que partem de relações participativas e incentivam o poder de ação e criação dos envolvidos. É também, e principalmente, a solidariedade que emerge das classes populares, especialmente entre as mulheres negras, para enfrentar as sucessivas crises que passam sem apoio do Estado.

\section{CONSIDERAÇÕES FINAIS}

A Economia Solidária é uma resposta da população ao desemprego, sobretudo da parcela historicamente excluída do mercado de trabalho formal, por meio da criação de atividades associativas e solidárias (CANÇADO, 2004). Na atuação com as classes populares, os grupos que a ITCP/Unicamp incuba têm uma composição muito semelhante entre si, com uma maioria de mulheres negras e pobres, e são atravessados por diversas questões que dificultam e desafiam a autogestão em sua prática cotidiana. Nesse sentido, os caminhos da autogestão se tornam abstrusos de trilhar, uma vez que a intersecção de opressões acaba estruturando barreiras complexas.

Apesar das aproximações, uma diferenciação importante é que tanto o Elizabeth Teixeira quanto a Santa Genebra contam com movimentos sociais que apoiam sua atuação, o MST e o MNCR, respectivamente. Embora os grupos incubados estejam distantes dos movimentos atualmente, existe um histórico de atuação e de conquistas que tem efeito sobre os grupos. Isso faz com que eles tenham o apoio de outros coletivos, vinculados ao mesmo setor, diante de dificuldades. Além disso, contam com alguns direitos conquistados e com experiências semelhantes de atuação bem sucedidas para se espelhar.

Contudo, o grupo de mulheres do Bassoli não tem esse apoio e horizonte. Apesar das múltiplas experiências de hortas urbanas existentes, não há um movimento social organizado. Ainda existe a dificuldade de convencer as pessoas do território a apostar na Economia Solidária e na Autogestão. Entretanto, deve-se ressaltar que não se trata apenas da dificuldade de convencimento. As mulheres do Bassoli são responsáveis pelas atividades de cuidado em suas casas. Assim, já realizam uma jornada de trabalho em suas residências. Ademais, por

\footnotetext{
${ }^{20}$ Ver artigo completo em: https:/www.thetricontinental.org/pt-pt/brasil/nos-por-nos-solidariedade-da-periferia-aperiferia-durante-o-coronachoque/. Acesso em: 30 ago. 2020.
} 
serem as responsáveis pelo cuidado dos filhos, a possibilidade de trabalharem fora é dificultada. Portanto, o desenvolvimento do grupo passa por pensar em como inserir em políticas de geração de trabalho e renda mulheres que já cumprem várias jornadas de trabalho em casa, que precisam cuidar dos filhos e não veem possibilidade de alcançar autonomia financeira.

Para além de inserir as mulheres, é preciso construir estratégias para que elas, mesmo no contexto da Economia Solidária, não sejam discriminadas por uma estrutura social patriarcal. $\mathrm{Na}$ Cooperativa Santa Genebra, único empreendimento com o qual a ITCP/Unicamp trabalha que não é formado exclusivamente por mulheres, a divisão do trabalho é feita com base em papéis de gênero. Também é comum a todos os grupos as múltiplas jornadas de trabalho devido aos cuidados com o lar. Na medida em que as mulheres, especialmente as negras e pobres, são as que mais têm dificuldade de se inserir na economia tradicional, a Economia Solidária precisa ser construída de forma a romper com esse quadro de exclusão.

Caracterizar a Economia Solidária em termos de gênero e raça é importante, inclusive, para se discutir os limites da autogestão nesses grupos. A estrutura racista e machista da sociedade colocou, por anos, as mulheres negras e pobres em atividades de subordinação. Isso se contrapõe a uma ideia de participação ativa. A autogestão prevê também a superação da divisão entre trabalho intelectual e manual. No entanto, há ainda no contexto atual essa divisão, sendo esses grupos os responsáveis pelo trabalho manual, tanto por sua associação com um trabalho subordinado quanto pela não associação à educação formal. Além disso, a meritocracia, característica de um modelo neoliberal, coloca a necessidade da prosperidade econômica associada ao esforço individual. Portanto, desenvolver a autogestão passa por desenvolver uma consciência coletiva e crítica, superando as dificuldades impostas por um histórico social de exclusão, e por trazer uma abordagem interseccional.

Ao longo do processo de incubação, pôde-se observar que diversas práticas de autogestão que foram propostas conflitaram com visões meritocráticas e carregadas por vícios das discriminações presentes na sociedade neoliberal. Isto é, as dinâmicas cotidianas do trabalho estiveram sujeitas às contradições em relação ao que se concebe como uma prática autogestionária comprometida com a emancipação dos grupos populares. Assim, deve-se fazer uma avaliação crítica do trabalho e reconhecer que parte das propostas não se aprofundou na discussão sobre machismo, racismo e meritocracia, o que, ao menos em parte, manteve a mentalidade capitalista por meio da qual a sociedade, especialmente a neoliberal, é formada. Ainda assim, os princípios teórico-metodológicos da Educação Popular, da Autogestão e da Tecnologia Social são fundamentais para aumentar as chances dos EES romperem com a lógica capitalista em sua expressão neoliberal.

Deve-se ressaltar, no entanto, que quando se trata de grupos em vulnerabilidade social, para os quais a renda é uma questão urgente, a incubação também deve atuar no sentido de ajudar os empreendimentos a serem economicamente viáveis. Para o sucesso de experiências autogestionárias, é preciso tanto garantir sua sustentabilidade econômica quanto sua relação com outras experiências de mesma natureza. Desse modo, evita-se que o empreendimento fracasse por não conseguir prosperar economicamente e que, diante do sucesso, não degenere em um empreendimento capitalista (CANÇADO, 2004). Logo, o desenvolvimento da autogestão passa por criar meios para que os grupos consigam manter seu funcionamento e gerar renda para seus membros.

Diante disso, é necessário reconhecer que, apesar da autogestão e da Economia Solidária guiarem o trabalho das ITCPs, atentar para as necessidades imediatas dos grupos também faz parte desse processo de construção. A Cooperativa Santa Genebra, assim como todas as 
cooperativas de catadores de Campinas, luta constantemente contra o avanço da terceirização e do setor privado na gestão de resíduos da cidade. No Elizabeth Teixeira, o poder público frequentemente coloca empecilhos para a regularização do pré-assentamento; com isso, os semterra lidam com a falta de saneamento, energia elétrica e água. Isso impacta tanto a qualidade de vida quanto a produção das cestas de alimentos. O Jardim Bassoli é fruto de um processo de urbanização que coloca a população mais vulnerável nas periferias da cidade, onde o acesso a equipamentos sociais é dificultado, somado à falta de infraestrutura. Diante de um Estado que constrói políticas que beneficiam o setor privado em detrimento de políticas de proteção social, fortalecer os grupos, reconhecendo suas necessidades e atuando para superá-las, é necessário para o desenvolvimento de uma prática autogestionária.

A falta de condições adequadas para sua sobrevivência e a atuação do poder público mais para manter desigualdades do que superá-las é, por vezes, desmobilizante. Apesar das dificuldades de discutir e implantar a autogestão entre os grupos, há um grande potencial de resistência e ação entre eles. Segundo Marielle Franco,

\begin{abstract}
Ainda que essa realidade das desigualdades, que pavimenta a história brasileira, tenha maior impacto em toda a periferia, principalmente nas favelas, as mulheres desse amplo território não são marcadas pela carência, como aparece no discurso predominante da imprensa e do poder hegemônico. Assumiram papel de centralidade de ações criativas e de conquistas de políticas do Estado que atuaram no caminho inverso das desigualdades, ampliando direitos em várias dimensões humanas. Conquistaram, assim, alterações em seus territórios com força para disputar, na cidade, novas localizações no imaginário popular e para as relações humanas $(2017$, p. 91).
\end{abstract}

Essa centralidade das mulheres negras e periféricas nas ações de superação das dificuldades, não apenas no âmbito pessoal, mas também nos contextos em que estão inseridas, dialogam com a potência da atuação desse grupo na Economia Solidária, embora frequentemente seja feito apenas um recorte de classe quando se discutem os sujeitos que compõem esse setor.

As dificuldades da autogestão referem-se não apenas a dificuldades impostas pelo pensamento neoliberal, que promove uma cultura individualista e centrada na preocupação com o emprego e o salário, mas também ao fato de que os grupos excluídos da economia capitalista são atravessados por outras opressões (gênero e raça). Além disso, uma vez que o neoliberalismo aprofunda desigualdades, esse fenômeno atinge mais profundamente esses setores sociais historicamente marginalizados.

Retoma-se aqui, então, o objetivo colocado pelo artigo em seu início. Nele foram propostas reflexões sobre os limites da Economia Solidária (ES) ao considerar que as principais acepções do termo não têm incorporado uma reflexão acerca das desigualdades raciais e de gênero. $\mathrm{O}$ caminho trilhado até aqui mostra que, na prática, as incubações cotidianas com as classes populares apresentam as questões de gênero e raça como estruturantes e ignorá-las é um erro não apenas metodológico, mas também teórico.

Reitera-se, portanto, como conclusão deste artigo, que há ainda um caminho teórico a ser colocado como prioridade. A pergunta que se mantém é: De que maneira o histórico, os conceitos e as reflexões sobre Economia Solidária ainda carregam em seu cerne o sujeito universal homem, branco europeu como protagonista? Além disso, ao reconhecer que, por meio da solidariedade popular, são as mulheres, negras e pobres que vêm construindo as alternativas de trabalho, de cuidado e de sociedade, elas deveriam ser colocadas no centro do imaginário e das ações na prática da Economia Solidária. 


\section{REFERÊNCIAS}

ANDERSON, Perry. Balanço do neoliberalismo In: SADER, Emir; GENTILI, Pablo. (Orgs.). Pós-neoliberalismo: as políticas sociais e o Estado democrático. Rio de Janeiro: Paz e Terra, 1995, p. 9-23.

CANÇADO, Airton Cardoso. Autogestão em cooperativas populares: os desafios da prática. 2004. Dissertação (Mestrado em Administração) - Universidade Federal da Bahia, Salvador, 2004.

CASTILHO, A. L. Partido da Terra: como os políticos conquistam o território brasileiro. São Paulo: Contexto, 2012.

CRENSHAW, Kimberlé. A intersecionalidade na discriminação de raça e gênero. VV. AA. Cruzamento: raça e gênero. Brasília: Unifem, 2004. p. 7-16.

COSTA, R. P.. Incubadoras Tecnológicas de Cooperativas Populares. In: Felipe Addor e Camila Rolim Laricchia. (Org.). Incubadoras tecnológicas de economia solidária. 1ed.Rio de Janeiro: Editora da UFRJ, 2018, v. I, p. 151-165.

DIEESE - Departamento Intersindical de Estatística e Estudos Socioeconômicos. A informalidade urbana. In: A situação do trabalho no Brasil na primeira década dos anos 2000. São Paulo: DIEESE, 2012a. Cap 8. p. 165-185.

DIEESE - Departamento Intersindical de Estatística e Estudos Socioeconômicos. O negro no mercado de trabalho. In: A situação do trabalho no Brasil na primeira década dos anos 2000. São Paulo: DIEESE, 2012b. Cap 10. p. 199-214.

FIGUEREDO, Angela. Perspectivas e contribuições das organizações de mulheres negras e feministas negras contra o racismo e o sexismo na sociedade brasileira. Direito e Práxis Revista, Rio de Janeiro, v. 9, n. 2, 2018, p. 1080-1099.

FRAGA, L. Extensão e transmissão de conhecimento: As Incubadoras Tecnológicas de Cooperativas Populares. 2012. Tese (Doutorado em Política Científica e Tecnológica) Instituto de Geociências, Universidade Estadual de Campinas, Campinas, 2012. Disponível em: http://repositorio.unicamp.br/bitstream/REPOSIP/286682/1/Fraga_LaisSilveira_D.pdf. Acesso em: 18 dez. 2020.

FRAGA, L. Transferência de conhecimento e suas armadilhas na extensão universitária brasileira. Avaliação, Campinas/Sorocaba, v. 22, n. 2, p. 403 - 419, jul. 2017.

FRANCO, Marielle. A emergência da vida para superar o anestesiamento social frente à retirada de direitos: o momento pós-golpe pelo olhar de uma feminista, negra e favelada. In: BUENO, Winnie et al. (Org.). Tem saída? Ensaios críticos sobre o Brasil. Porto Alegre: Zouk, 2017.

HIRATA, Helena; KERGOAT, Danièle. Novas configurações da divisão sexual do trabalho. Cad. Pesqui. [on-line], v. 37, n. 132, p. 595-609, 2007.

HOOKS, Bell. Pensamento Feminista: na sala de aula agora. In: HOOKS, Bell. Ensinando a transgredir: a educação como prática da liberdade. Tradução de Marcelo Brandão Cipolla. São Paulo: Editora WMF Martins, 2013. p. 151-160.

IBGE - Instituto Brasileiro de Geografia e Estatística. Síntese de indicadores sociais: uma análise das condições de vida da população brasileira. Rio de Janeiro: IBGE, 2019. 
IPEA - Instituto de Pesquisa Econômica Aplicada. A organização coletiva de catadores de material reciclável no Brasil: dilemas e potencialidades sob a ótica da economia solidária. Rio de Janeiro: IPEA, 2017.

ITCP/Unicamp - Incubadora Tecnológica de Cooperativas Populares da Universidade Estadual de Campinas. Problemas e entraves na gestão de resíduos sólidos: desafios na construção da Rede Solidária na cidade de Campinas-SP. Coletiva II: Sistematizações sobre a Prática Autogestionária, Campinas, n. 2, 2013.

LABUTA: Racismo e História do Trabalho com Ynaê Lopes dos Santos e Antonio Sérgio A. Guimarães - LEHMT-UFRJ. Rio de Janeiro: LEHMT-UFRJ, 2020. 1 vídeo (1h51min). Disponível em https://www.youtube.com/watch?v=SR86e9TskUw. Acesso em: 2 jul. 2020.

LAVAL, Christian; DARDOT, Pierre. A nova razão do mundo: ensaio sobre a sociedade neoliberal. São Paulo: Boitempo, 2016.

MINTO, Lalo Watanabe. A educação da miséria: particularidade capitalista e educação superior. 2011. 215 f. Tese (Doutorado) - FE/Unicamp, Campinas, 2010.

NASCIMENTO, Cláudio. Do Beco dos Sapos aos canaviais de Catende. Marília: Lutas Anticapital, 2019.

NOIS - Núcleo de Operações e Inteligência em Saúde. Diferenças sociais: pretos e pardos morrem mais de COVID-19 do que brancos, segundo NT11 do NOIS, 2020. Disponível em:http://www.ctc.puc-rio.br/diferencas-sociais-confirmam-que-pretos-e-pardos-morremmais-de-covid-19-do-que-brancos-segundo-nt11-do-nois/. Acesso em: 30 ago. 2020.

OÃO, Larissa Vieira. Minha Casa, Minha Vida: a produção capitalista da habitação e do espaço urbano no município de Campinas-SP o Residencial Bassoli como um estudo de caso. 2012. TCC (Graduação em Geografia) - Instituto de Geociências, Universidade Estadual de Campinas, Campinas, 2012. p. 97.

OLIVEIRA, Denise. Percepção de riscos ocupacionais em catadores de materiais recicláveis: estudo em uma cooperativa em Salvador-Bahia. 2011. Dissertação (Mestrado em Saúde) Universidade Federal da Bahia, Salvador, 2011.

OLIVEIRA, A. U. A Geografia Agrária e as transformações territoriais recentes no campo brasileiro. In: Ana Fani Alessandri Carlos. (Org.). Novos caminhos da geografia. São Paulo: Contexto, 1999, v. , p. -.

OLIVEIRA, A. U.. Terras de estrangeiros no Brasil. 1. ed. São Paulo: Iandé Editorial, 2018. v. $1.267 \mathrm{p}$.

ONU Mulheres. Declaração e Plataforma de Ação da IV Conferência Mundial Sobre a Mulher. Pequim, 1995. Disponível em: http://www.onumulheres.org.br/wp-content/ uploads/2014/02/declaracao_pequim.pdf. Acesso em: 28 ago. 2020.

PRADO Jr. Caio. A Questão Agrária no Brasil. São Paulo: Brasiliense, 2000.

REIS, Tássia. Da Lama / Afrontamento. São Paulo: Bertelsmann Music Group. Disponível em: https:/www.youtube.com/watch?v=6MRkuIK08ZU. Acesso em: 19 jul. 2020.

SILVA, Carlúcia Maria. Trabalho, Economia Solidária e catadores de recicláveis: desigualdades de gênero e de raça, em busca da cidadania. Revista da ABET, v. 13, n. 2, jul.- dez. 2014. 
SILVA, Márcia Nazaré. A Economia Solidária e as novas possibilidades do mundo do trabalho, Âmbito Jurídico, 2011. Disponível em https://ambitojuridico.com.br/edicoes/revista100/a-economia-solidaria-e-as-novas-possibilidades-do-mundo-do-trabalho/. Acesso em: 28 ago. 2020 .

SINGER, Paul. Introdução à Economia Solidária. Editora Fundação Perseu Abramo: São Paulo, 2002.p.110.

SOARES, Sergei. As políticas públicas e a desigualdade racial no Brasil: 120 anos após a abolição. Brasília: Ipea, 2008. Cap. 1. p. 15-43.

TIRIBA, Lia. Educação popular e pedagogia(s) da produção associada. Cad. CEDES, Campinas, v. 27, n. 71, p. 85-98, abr. 2007 . Disponível em http://www.scielo.br/scielo.php?script=sci_ arttext\&pid=S0101-32622007000100006\&lng=pt\&nrm=iso. Acesso em: 28 ago. 2020.

THEODORO, Mário. A formação do mercado de trabalho e a questão racial no Brasil In: THEODORO, Mário (Org.).; JACCOUD, Luciana; OSÓRIO, Rafael Guerreiro; SOARES, Sergei. As políticas públicas e a desigualdade racial no Brasil: 120 anos após a abolição. Brasília: IPEA, 2008. p. 15-43.

VARGAS, Isabel Cristina de. Efeitos do cruzamento de gênero, raça e classe na vida de trabalhadoras de um empreendimento de reciclagem: uma leitura através da interseccionalidade. 2019. Dissertação (Mestrado em Ciências Sociais) - Universidade do Vale do Rio dos Sinos, São Leopoldo, 2019.

VERAS NETO, Francisco Quintanilha. Autonomia Coletiva na Economia Solidária. Juris, Rio Grande, ed. comemorativa 45 anos, p 283-297, 2005. Disponível em: http://repositorio. furg.br/xmlui/bitstream/handle/1/5172/Autonomia $\% 20$ coletiva $\% 20$ na $\% 20$ economia $\% 20$ solid\%C3\%A1ria.pdf?sequence=1. Acesso em: 28 ago. 2020 .

Recebido em: $31 / 08 / 2020$

Aceito para publicação em: 30/11/2020 